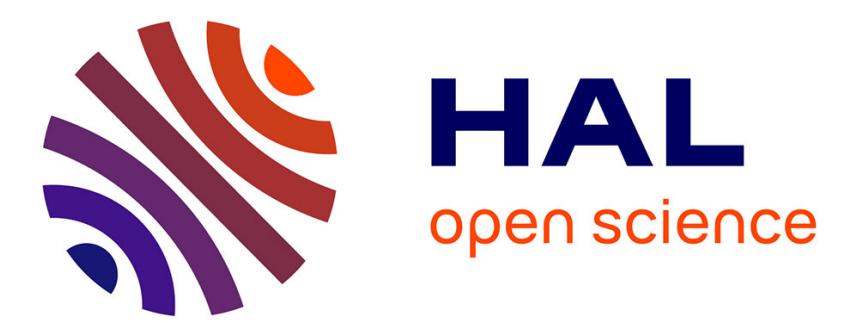

\title{
The effects of cavity length on nest size, sex ratio and mortality of Centris (Heterocentris) analis (Hymenoptera, Apidae, Centridini)
}

\author{
Juliana Alonso, Janaina Silva, Carlos Garófalo
}

\section{To cite this version:}

Juliana Alonso, Janaina Silva, Carlos Garófalo. The effects of cavity length on nest size, sex ratio and mortality of Centris (Heterocentris) analis (Hymenoptera, Apidae, Centridini). Apidologie, 2012, 43 (4), pp.436-448. 10.1007/s13592-011-0110-0 . hal-01003534

\section{HAL Id: hal-01003534 \\ https://hal.science/hal-01003534}

Submitted on 1 Jan 2012

HAL is a multi-disciplinary open access archive for the deposit and dissemination of scientific research documents, whether they are published or not. The documents may come from teaching and research institutions in France or abroad, or from public or private research centers.
L'archive ouverte pluridisciplinaire HAL, est destinée au dépôt et à la diffusion de documents scientifiques de niveau recherche, publiés ou non, émanant des établissements d'enseignement et de recherche français ou étrangers, des laboratoires publics ou privés. 


\title{
The effects of cavity length on nest size, sex ratio and mortality of Centris (Heterocentris) analis (Hymenoptera, Apidae, Centridini)
}

\author{
Juliana D. S. Alonso, Janaina F. Silva, Carlos A. Garófalo \\ Departamento de Biologia, Faculdade de Filosofia, Ciências e Letras de Ribeirão Preto-USP, 14040-901 \\ Ribeirão Preto, SP, Brazil
}

Received 5 February 2011 - Revised 12 October 2011 - Accepted 25 October 2011

\begin{abstract}
This study investigated the effects of different cavity lengths in trap-nests on the number of cells constructed per nest, sex ratio and mortality of offspring of Centris analis at three sites in Ribeirão Preto, São Paulo, Brazil. Cavity length did not affect the occupation rates of the trap-nests, with the exception of a preference for the shortest trap-nests found at one site. The number of cells per nest increased with trap-nest length. Cavity length affected neither brood cell size, the arrangement of sexes in the nests, nor the rates of immature mortality from parasitism or other causes, with the exception of one case. Cavity length influenced the sex ratio of offspring, with male-biased sex ratios decreasing as the length of the trap-nest increased. This study showed that an increase in the production of $C$. analis females can be achieved by increasing trap-nest length.
\end{abstract}

Centris analis / trap-nest / sex ratio / immature mortality / natural enemy

\section{INTRODUCTION}

Studies conducted in Brazil on communities of solitary cavity-nesting bees have shown that several Centris species occupy trap-nests (Garófalo et al. 2004), and among them, Centris analis (Fabricius) and Centris tarsata Smith usually nest at the highest frequencies (Camillo et al. 1995; Garófalo 2000; Morato and Campos 2000; Viana et al. 2001; Aguiar and Martins 2002; Buschini 2006; Gazola and Garófalo 2009). These species' acceptance of a wide variety of trap-nests, their abundance, their occurrence in different habitats, as well as information concerning their association with some fruit crops (Freitas 1997; Freitas and

Corresponding author: C.A. Garófalo, garofalo@ffclrp.usp.br

Manuscript editor: Yves Le Conte
Paxton 1998; Freitas et al. 1999; Castro 2002) led Garófalo et al. (2004) to suggest that they, together with Centris vittata Lepeletier, would be good candidates for pollination programs. Recently, Oliveira and Schlindwein (2009) demonstrated the potential of $C$. analis as a pollinator of Acerola, also called West Indian cherry (Malpighia emarginata DC.; Malpighiaceae), and they recommended this species as an excellent candidate for use as a managed pollinator in orchards. According to those authors, however, to make commercial use of C. analis possible, further studies are necessary regarding immature development, the control and manipulation of adult emergence and methods for controlling natural enemies. Additionally, the optimal number of bees per area must be determined to maximize fruit set, and a procedure must be established for introducing occupied trap-nests to a new site. These 
recommendations are in accordance with those presented by Bosch and Kemp (2002) for developing and establishing bee species as crop pollinators.

Successful nesting of managed pollinator populations is essential for efficient crop pollination (Bosch 1994b; Bosch and Kemp 2001; Pitts-Singer and James 2005; Maccagnani et al. 2007). The dimensions of trap-nests are among several factors that play key roles in determining nesting success because they affect not only female establishment but also the sex ratio and body size of progeny as well as overall progeny survival (Maeta 1978; Tepedino and Parker 1983; Tepedino and Torchio 1989; Bosch 1994a, b; Vicens et al. 1994; Bosch and Kemp 2001, 2002).

Centris (Heterocentris) analis is a solitary bee with a broad geographic range extending from Mexico to Brazil (Moure 1960). In a detailed study of the nesting behavior of $C$. analis, Vieira de Jesus and Garófalo (2000) reported that the bees constructed their nests with plant material and an oily substance. Completed nests occupying trap-nests $5.8 \mathrm{~cm}$ in length and $0.6 \mathrm{~cm}$ in internal diameter had one to four brood cells arranged in a linear series, usually followed by a vestibular cell, an empty cell found between the last brood cell and the nest plug. The innermost cells of the nests produced females, and the outermost cells produced males. The egg-to-adult period was affected by climatic conditions and ranged from 36 to 85 days for males and from 37 to 88 days for females. Nests were parasitized by the wasp Leucospis cayennensis Westwood and by the bees Coelioxys sp. (Megachilidae) and Mesocheira bicolor (Fabricius) (Apidae). The parasitic behavior of L. cayennensis, together with the rates of parasitism and other mortality factors in populations of $C$. analis, were reported by Gazola and Garófalo (2003).

In this study we investigated the effects of different cavity lengths in trap-nests on the number of cells per nest, on sex ratio and on the survival of the progeny produced. In addition, new data concerning phenology, immature development and natural enemies are reported.

\section{MATERIALS AND METHODS}

This study was carried out at three sites in the municipality of Ribeirão Preto in the state of São Paulo, Brazil. Site $\mathrm{I}$ is on the campus of the University of São Paulo $\left(21^{\circ} 05^{\prime}-21^{\circ} 15^{\prime} \mathrm{S}\right.$ and $47^{\circ}$ $50^{\prime}-47^{\circ} 55^{\prime \prime} \mathrm{W}$ ), which occupies a 189.37 ha site with university buildings, a residential area and a 75 ha area planted with tree species typical of semideciduous forests, such as Guazuma ulmifolia Lam. (Malvaceae), Trema micrantha (L.) Blume (Cannabaceae), Cecropia pachystachya Trécul (Urticaceae), Cedrela fissilis Vell. (Meliaceae), Chorisia speciosa A. St.- Hil (Bombacaceae), Schyzolobium parahyba (Vell.) Blake (Fabaceae), Cariniana estrellensis (Raddi) Kuntze (Lecythidaceae), and Gallesia integrifolia (Spreng.) Harms (Phytolaccaceae). Native and exotic trees and shrubs occur in a grassy matrix, with gardens and fruit trees scattered throughout (Pais and Varanda 2010). Site II is a small farm $\left(21^{\circ} 11^{\prime}\right.$ $27.4^{\prime \prime} \mathrm{S}-47^{\circ} 42^{\prime} 46.2^{\prime \prime} \mathrm{W}$ ) with an area of 0.1 ha. In addition to the house of the landowner, the site included specimens of ornamental plants and fruit trees such as Mangifera sp. (Anacardiaceae) and Malpighia glabra Linn (Malpighiaceae) and specimens of the families Rutaceae, Balsaminaceae, Bignoniaceae, Caricaceae, Cruciferae-Brassicaceae, Euphorbiaceae, Lamiaceae, Melastomataceae, Myrtaceae, Musaceae, Oxalidaceae, Rubiaceae, Rosaceae and Sapindaceae. This small farm, together with other properties, forms a continuum surrounded by sugarcane monocultures (Saccharum officinarum L.) (Poaceae). Site III is a small private property including a house (0.03 ha) $\left(21^{\circ} 11^{\prime} 06.2^{\prime \prime} \mathrm{S}-47^{\circ} 50^{\prime} 17.9^{\prime \prime} \mathrm{W}\right)$ with some ornamental plants and at least one fruit tree (Mangifera sp. (Anacardiaceae)); this property is surrounded by similar properties with ornamental plants, shade trees and fruit trees. Site I is $15.7 \mathrm{~km}$ from Site II and $3.38 \mathrm{~km}$ from Site 3; and Site 2 is $13 \mathrm{~km}$ from Site 3.

The local climate has two well-defined seasons: a cool/dry season extending from May to August, with a mean monthly temperature ranging from $19.5^{\circ} \mathrm{C}$ to $22.8^{\circ} \mathrm{C}$ and precipitation from 0 to $98.6 \mathrm{~mm}$, and a hot/wet season extending from September to April, with a mean monthly temperature ranging from $22.8^{\circ} \mathrm{C}$ to $26.1^{\circ} \mathrm{C}$ and precipitation from 3 to $469.9 \mathrm{~mm}$. Records on temperature and precipitation 
for January 2006 to November 2007 were obtained from the Centro Integrado de Informações Agrometereológicas (CIIAGRO 2011).

In accordance with Vieira de Jesus and Garófalo (2000), the trap-nests used in this study consisted of tubes made of black cardboard closed at one end. The tubes measured 5.5, 6.0, 6.5 and $7.0 \mathrm{~cm}$ in length and $0.6 \mathrm{~cm}$ in internal diameter and were inserted into horizontal holes drilled into wooden plates (length $30 \mathrm{~cm}$, height $12 \mathrm{~cm}$, thickness $5.0 \mathrm{~cm}$ ). Each wooden plate had a total of 52 available holes spaced $2.0 \mathrm{~cm}$ apart and distributed in five rows (Figure 1). At Site I, a total of 65 tubes (hereafter "trap-nests") of each dimension were distributed among five wooden plates. At Site II, 26 trap-nests of each dimension were distributed between two wooden plates, and at Site III, 13 trap-nests of each dimension were distributed throughout one wooden plate. At all sites, the plates were placed on shelves kept under a roof made of wood to provide protection to the nests from the weather. The shelves were positioned $1.5 \mathrm{~m}$ from the ground. The trap-nests were displayed in the wooden plates in order from the shortest to the longest length, beginning with the first row and continuing counter-clockwise; this pattern was repeated until all of the holes were filled with trapnests. Changes in the sequence were made only to prevent two trap-nests of the same length from being displayed side-by-side.

During the study period, the trap-nests were inspected with an otoscope (ear scope) every day and information was recorded for trap-nests with active and completed nests. Female activity was monitored throughout the nesting period for a total of 2,350 h. All occupied trap-nests at each site were taken to the laboratory 10 days after being completed and replaced with a similar trap-nest. In the laboratory, each trap-nest with a completed nest was placed in a transparent glass tube $4.0 \mathrm{~cm}$ longer than the trap-nest and with an internal diameter of $0.9 \mathrm{~cm}$. The trap-nests were kept at room temperature (21$29^{\circ} \mathrm{C}$ ) and observed daily until the adults emerged. After emergence, the bees were released at Site I. Before release, the females were placed in individual glass vials, transferred to a refrigerator maintained at $6^{\circ} \mathrm{C}$ until their movements were reduced. After that, they were marked with spots of color on their scutum to facilitate the identification of each individual. At Site II, 46 females from the native population were marked after beginning their nesting activities in the traps. In these cases, the females were removed from their nests at night and the procedure to mark them followed the same methodology showed before.

Fecundity was defined as the total number of cells made by individual females per study area.

Ten to fifteen days after the last emergence from a given nest, the nest was opened, and its contents were analyzed. Cells and nests from which nothing emerged were also opened. The presence and identification of parasites was recorded, and where other causes of death were unknown, the bee life stage at death was recorded.

The study was conducted from January 2006 to November 2007 at Site I and from January to November 2007 at Sites II and III.
Figure 1. Partial view of a wooden plate with trap-nests placed in holes drilled in it. Three Centris analis females can be seen at the entrance of their nests.

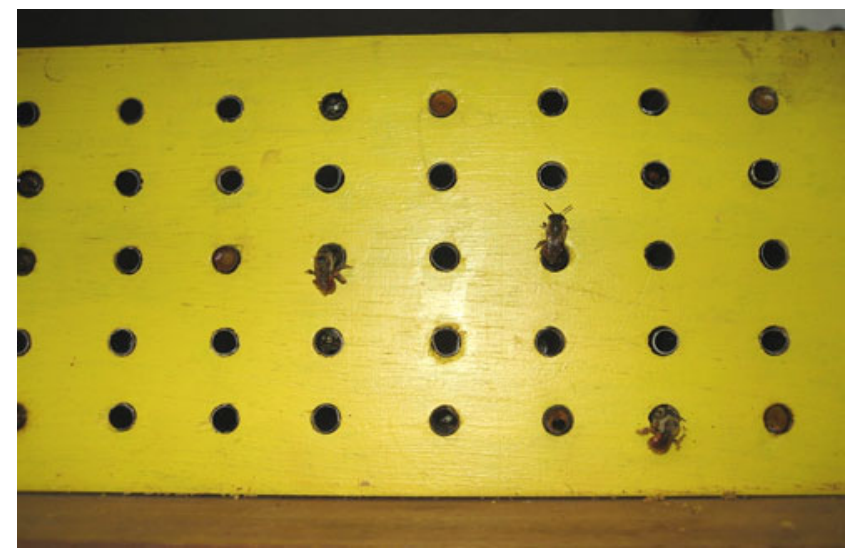




\subsection{Statistical analyses}

The statistical tests followed Zar (1984) and were performed using the statistical packages SigmaPlot 11.0 (Systat Software Inc. 2008). Chi-square goodness of fit tests were used to analyze the relationship between length of trap-nest and the frequency of occupation of the trap-nest, the production of females, to check the extent to which the observed sex ratio deviated from the expected frequency (1 female: 1 male), and to analyze differences in progeny sex ratio among nests of different lengths and nests from different sites. Heterogeneity chisquare tests were used to analyze the rates of immature mortality and parasitism. Pearson correlation analyses were performed to verify the intensity of the associations between the number of cells constructed by each female and her period of activity as well as between the number of cells per nest and the production of females in each cell. The normality of data was analyzed by the Shapiro-Wilk test. The Mann-Whitney test was used to compare the total number of cells produced by individual females nesting at Sites I and II, the periods of time in days that those females nested in each site, the lengths of male and female cells, and the duration of the egg-toadult periods for both sexes in each season, between seasons and at each site (I and II). The influence of trapnest length on the number of brood cells constructed per nest and on the dimensions of male and female cells was analyzed by the Kruskal-Wallis test. Throughout the text, all means $(\mathrm{x})$ are given $\pm \mathrm{SE}$.

\section{RESULTS}

\subsection{Nesting phenology}

During the study periods, 91 nests were established at Site I, 76 nests at Site II and 54 nests at Site III. At Sites I and II, most nesting occurred during the hot, wet season (September to April) (Figure 2), whereas at Site III, nesting occurred exclusively in the hot,wet months of March, September and November. At Site I, the highest frequencies of nesting were observed in December 2006 (34.4\%) and November 2007 $(37.3 \%)$; at Site II, they occurred in October $(26.3 \%)$ and November (30.2\%), and at Site III,

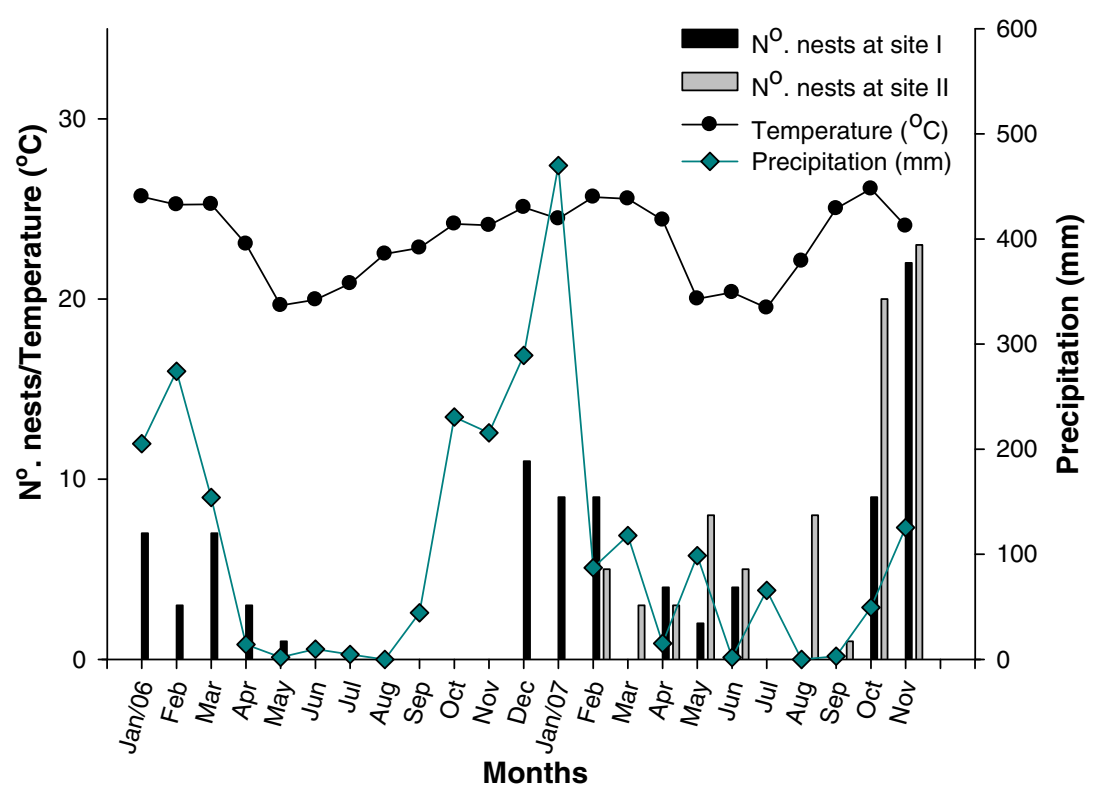

Figure 2. Bars show the number of nests constructed by Centris analis from January 2006 to November 2007 at Site I and from January 2007 to November 2007 at Site II. Lines show the temperature and precipitation for the same time period. 
they occurred in September (31.5\%) and November $(51.8 \%)$.

\subsection{Use of different trap-nests by $C$. analis females}

At Site I, most nests were built in trap-nests of the shortest length, whereas at Sites II and III, no significant difference was observed in the frequency at which trap-nests of different lengths were used (Table I).

\subsection{Nesting activities of Centris analis}

At Site I, of the 75 paint-marked females, 59 nested in the trap-nests making a total of 91 nests and 277 brood cells, whereas at Site II, of the 52 paint-marked females, 46 built 76 nests and 260 brood cells. The number of nests constructed by each female ranged from one (38 females at Site I and 26 females at Site II) to four at Site II (two females) and six at Site I (one female). The number of brood cells constructed by each female ranged from one (three females) to 18 (one female) at Site I and from two (one female) to 12 (five females) at Site II. The fecundity was significantly highest for females that nested at Site II (MannWhitney test, $Z=-2.46 ; P<0.05$ ), and the periods that the females remained nesting in each area were not significantly different (Mann-Whitney test, $Z=-0.92 ; P>0.05$ ) (Table II). The number of cells constructed by each female was significantly correlated with her period of activity $(r=0.9$ and $r=0.96 ; P<$ 0.05 , for Sites I and II, respectively).

\subsection{Length of trap-nests and number of brood cells per nest}

Regardless of the trap-nest occupied, the number of brood cells in completed trap-nests $(n=221)$ ranged from one $(n=9)$ to five $(n=5)$, with three brood cells being the most frequent number in the shortest trap-nest and five brood cells found only in the longest trap-nest (Figure 3). The number of cells per nest was significantly smaller in $5.5 \mathrm{~cm}$ trap-nests than in those 6.0, 6.5 and $7.0 \mathrm{~cm}$ in length (Kruskal-Wallis and Dunn's method, $H=45.9 ; P<0.001)$.

\subsection{Trap-nest length and number of females produced}

The number of females produced per nest did not differ between those established in the two shortest trap-nests $(5.5$ and $6.0 \mathrm{~cm})\left(\chi^{2}=0.001\right.$; $\mathrm{df}=3 ; P>0.05)$ or between those established in the two longest ones $(6.5$ and $7.0 \mathrm{~cm})\left(\chi^{2}=1,69\right.$; $\mathrm{df}=3 ; P>0.05)$, but it did differ when comparing the two shortest with the two longest trapnests $\left(\chi^{2}=30.0 ; \mathrm{df}=9 ; P<0,001\right)$ (Table III).

\subsection{Brood cell size}

Analysis of variance showed that trap-nest length modified neither the dimensions of the female cells (Kruskal-Wallis test, $H=4.39$; df= 3; $P>0.05)$ nor the dimensions of the male cells (Kruskal-Wallis test, $H=3.43 ; \mathrm{df}=3 ; P>0.05$ ). In contrast, regardless of the trap-nest utilized, female cells (range: $1.10-1.67 \mathrm{~cm} ; x=1.37 \pm$ $0.11 \mathrm{~cm} ; n=181$ ) were significantly longer than

Table I. Frequency of nesting by Centris analis females in trap-nests of different lengths, from January 2006 to November 2007 at Site I, and from January to November 2007 at Sites II and III.

\begin{tabular}{|c|c|c|c|c|c|c|}
\hline \multirow[t]{2}{*}{ Site } & \multicolumn{4}{|c|}{ Trap-nest length (cm) } & \multirow[t]{2}{*}{ Number of nests } & \multirow[t]{2}{*}{$\mathrm{X}^{2}$} \\
\hline & 5.5 & 6.0 & 6.5 & 7.0 & & \\
\hline I & $36^{\mathrm{a}}$ & $25^{\mathrm{b}}$ & $12^{\mathrm{c}}$ & $18^{\mathrm{b}}$ & 91 & $14.01, \mathrm{df}=3$ \\
\hline II & $19^{\mathrm{a}}$ & $20^{\mathrm{a}}$ & $16^{\mathrm{a}}$ & $21^{\mathrm{a}}$ & 76 & $0.74, \mathrm{df}=3$ \\
\hline III & $15^{\mathrm{a}}$ & $12^{\mathrm{a}}$ & $13^{\mathrm{a}}$ & $14^{\mathrm{a}}$ & 54 & $0.37, \mathrm{df}=3$ \\
\hline
\end{tabular}

${ }^{a}$ Values followed by the same letter in the same row are not significantly different at $P<0.05$ 
Table II. Number of nests, cells, fecundity and period of activity spent by individually marked Centris analis females in nest construction at Site I, from January 2006 to November 2007, and at Site II, from January to November 2007.

\begin{tabular}{lcc}
\hline & Site I & Site II \\
\hline Females nesting & 59 & 46 \\
Total number of nests & 91 & 76 \\
Total number of cells & 277 & 260 \\
Fecundity $^{\mathrm{a}, \mathrm{b}}$ & $4.7 \pm 0.42(1-18)^{\mathrm{a}}$ & $5.6 \pm 0.44(2-12)^{\mathrm{b}}$ \\
Period of activity $^{\mathrm{a}, \mathrm{c}}$ & $5.9 \pm 0.54(1-22)^{\mathrm{a}}$ & $6.2 \pm 0.51(2-15)^{\mathrm{a}}$ \\
\hline
\end{tabular}

${ }^{\mathrm{a}}$ Mean $\pm \mathrm{SE}$ (range); ${ }^{\mathrm{b}}$ number of constructed cells per female; ${ }^{\mathrm{c}}$ in days. Values in the same row followed by different letters are significantly different at $P>0.05$

male cells (range: $0.83-1.60 \mathrm{~cm} ; x=1.26 \pm 0.12$; $n=28$ ) (Mann-Whitney test: $Z=-3.87$ for 5.5 cm traps, $Z=-4.30$ for $6.0-\mathrm{cm}$ traps, $Z=-4.76$ for $6.5-\mathrm{cm}$ traps and $Z=-3.83$ for $7.0-\mathrm{cm}$ traps; $P<0.01$ for all).

\subsection{Sequence of sexes and sex ratios in nests}

Regardless of trap-nest length, in nests that produced both sexes, females were always reared in the innermost cells and males were reared in cells that were closer to the trap-nest entrance. When analyzing the production of females, both those that emerged and those that died in the cell, significant correlations were observed between the length of the trap-nest and the percentage of females produced from the first (innermost) cell $(r=-0.98 ; P<0.05 ; n=4)$ and from the third cell $(r=0.96 ; P<0.05 ; n=4)$.
These results indicate that the decrease in the percentage of females in the first cell of the nests was due to higher production of females in the third cell as the length of trap-nests increased (Figure 4).

The sex ratio of the 440 individuals, both emerged and dead in the cell, produced from the nests collected at Sites I, II and III, was $63.0 \%$ males to $37.0 \%$ females, significantly different from a $1: 1$ sex ratio $\left(\chi^{2}=29.53 ; \mathrm{df}=1 ; P<0.05\right)$. When considering the individuals produced in trap-nests by length, the two shortest trap-nests had male-biased sex ratios: $2.47 \mathrm{M}: 1 \mathrm{~F}$ in the 5.5-cm trap-nests $\left(\chi^{2}=19.9 ; \mathrm{df}=1 ; P<0.05\right)$ and $1.83 \mathrm{M}: 1 \mathrm{~F}$ in the 6.0 -cm trap-nests $\left(\chi^{2}=9.96\right.$; $\mathrm{df}=1 ; P<0.05)$; whereas in the two longest trapnests, the sex ratios were not significantly different from a $1: 1$ sex ratio: $1.38 \mathrm{M}: 1 \mathrm{~F}$ in the 6.5-cm trap-nests $\left(\chi^{2}=2.08 ; \mathrm{df}=1 ; P>0.05\right)$
Figure 3. Percentage of Centris analis nests in all three study areas with the indicated number of constructed brood cells according to trap-nest length from January 2006 to November 2007 at Site I and from January to November 200 at Sites II and III. (Bars topped by different letters are significantly different at $P<0.001$ ).

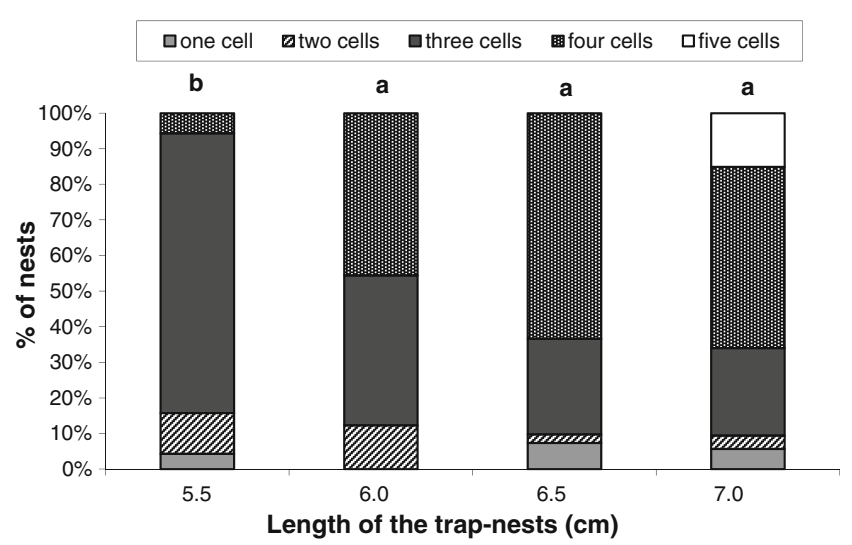


Table III. Number of females produced per nest established in trap-nests of different cavity length from January 2006 to November 2007 at Site I, and from January to November 2007 at Sites II and III.

\begin{tabular}{ccccc}
\hline Number of females & \multicolumn{4}{c}{ Number of nests producing females } \\
\cline { 2 - 5 } produced per nest & $5.5 \mathrm{~cm}$ & $6.0 \mathrm{~cm}$ & $6.5 \mathrm{~cm}$ & $7.0 \mathrm{~cm}$ \\
\hline 1 & 24 & 27 & 13 & 23 \\
2 & 7 & 8 & 9 & 10 \\
3 & 0 & 0 & 2 & 4 \\
4 & 0 & 0 & 1 & 1 \\
& \multicolumn{2}{c}{$\mathrm{x}^{2}=0.001, \mathrm{df}=3 ; p>0.05$} & $\mathrm{x}^{2}=1.69, \mathrm{df}=3 ; p>0.05$ \\
& \multicolumn{2}{c}{$\mathrm{x}^{2}=30.03, \mathrm{df}=9 ; p<0.001$} \\
\hline
\end{tabular}

and $1.35 \mathrm{M}: 1 \mathrm{~F}$ in the $7.0-\mathrm{cm}$ trap-nests $\left(\chi^{2}=\right.$ 3.03; $\mathrm{df}=1 ; P>0.05)$. Similar results were obtained in analyses of the nesting sites, thus reinforcing the tendency of the sex ratio bias toward males to disappear with increasing trapnest length (Table IV).

\subsection{Egg-to-adult period}

In nests constructed during the hot, wet season (September-April), no significant difference was found in the egg-to-adult period between males (range: 40-100 days, $x=52.1 \pm$ 10.5 days, $n=93$ for Site I; range: $41-94$ days, $x=51.1 \pm 9.7$ days, $n=87$ for Site II) and females (range: $42-97$ days, $x=52.5 \pm 9.7$ days, $n=41$, for Site I; range: $41-81$ days, $x=50.3 \pm 6.7$ days, $n=55$ for Site II) (Mann-Whitney test: $Z=-0.98$ and $Z=-0.72$ for Sites I and II, respectively; $P>$ $0.05)$. In nests made during the cool, dry season, a similar result was found for males (range: 5796 days, $x=77.7 \pm 19.6$ days, $n=3$ for Site I; range: $36-85$ days, $x=63.9 \pm 17.9$ days, $n=22$ for Site II) and females (range: 56-104 days, $x=$ $84.0 \pm 24.7$ days, $n=5$, for Site I; range: 3688 days, $x=59.2 \pm 20.9$ days, $n=16$ for Site II ) (Mann-Whitney test: $Z=-0.74$ and $Z=-0.82$ for Sites I and II, respectively; $P>0.05$ ). The times of development observed during each nesting period were significantly different between the sexes at Site I (Mann-Whitney test: $Z=-2.64$; $P<0.05$ for males and $Z=-3.27 ; P<0.05$ for females) and for males at Site II (MannWhitney test: $Z=-2.35 ; P<0.05)$, but no difference was found for females at Site II (MannWhitney test: $Z=-0.15 ; P>0.05)$.

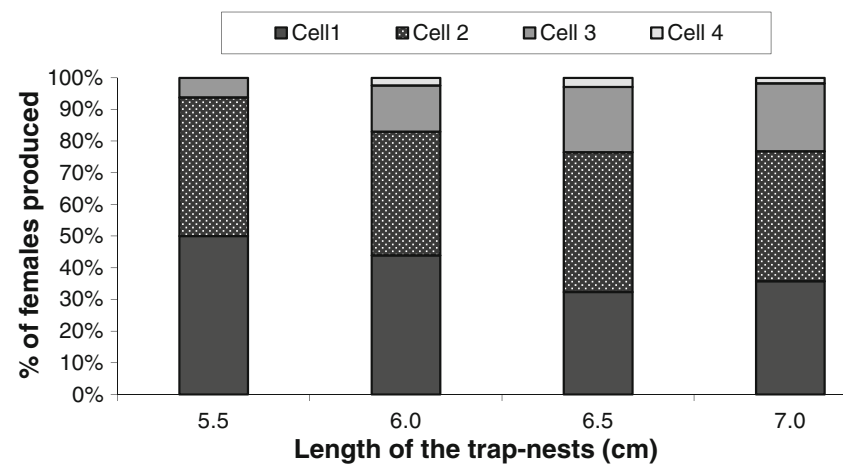

Figure 4. Percentage of Centris analis females produced (both emerged and dead in the cell) per cell according to the construction order of the cell in nests established in trap-nests of different lengths from January 2006 to November 2007 at Site I and from January to November 200 at Sites II and III. (Cell $1=$ innermost cell and Cell 4 = outermost cell). 
Table IV. Sex ratios of Centris analis progeny found in trap-nests of different lengths obtained from January 2006 to November 2007 at Site I, and from January to November 2007 at Sites II and III.

\begin{tabular}{lcccc}
\hline Site & Length of trap-nest (in cm) & Males produced & Females produced & Sex ratio (male/female) \\
\hline I & 5.5 & 38 & 15 & $2.53: 1^{\mathrm{a}}$ \\
& 6.0 & 29 & 12 & $2.41: 1^{\mathrm{a}}$ \\
& 6.5 & 06 & 05 & $1.20: 1 \mathrm{NS}$ \\
& 7.0 & 24 & 14 & $1.71: 1 \mathrm{NS}$ \\
& 5.5 & 24 & 14 & $1.71: 1 \mathrm{NS}$ \\
II & 6.0 & 30 & 16 & $1.87: 1^{\mathrm{a}}$ \\
& 6.5 & 25 & 16 & $1.56: 1 \mathrm{NS}$ \\
& 7.0 & 30 & 26 & $1.15: 1 \mathrm{NS}$ \\
III & 5.5 & 17 & 03 & $1.67: 1^{\mathrm{a}}$ \\
& 6.0 & 16 & 13 & $1.23: 1 \mathrm{NS}$ \\
& 6.5 & 16 & 13 & $1.37: 1 \mathrm{NS}$ \\
\hline
\end{tabular}

${ }^{\text {a }}$ Significantly different from 1:1 at $P>0.05 ; \mathrm{NS}=$ not significantly different from 1:1 at $P<0.05$

3.9. Immature mortality and nest associates

Adult bees emerged from $440(60.6 \%)$ of the 726 cells constructed in nests established in the three study areas. Among the remaining cells, $252(34.7 \%)$ contained immature bees dead from unknown causes, and 34 (4.7\%) had been parasitized by the wasp Leucospis cayennensis Westwood (Chalcidoidea, Leucospidae). Most immatures $(53 \%)$ died in the egg stage or during the first instar, and the mortality rates of the different developmental stages did not differ among the nests in trap-nests of different lengths $\left(\chi^{2}=6.40 ; \mathrm{df}=6 ; P>0.05\right)$ (Figure 5).

A comparison among the mortality rates found for the nests from each area showed that the mortality rate at Site I (48.4\%) was the highest and was significantly higher than those at Sites II $(42.5 \%)$ and III $(38.6 \%)\left(\chi^{2}=18.24\right.$; $\mathrm{df}=2 ; P<0.05)$, which did not differ significantly from each other $\left(\chi^{2}=3.32 ; \mathrm{df}=1 ; P>0.05\right)$.

The mortality rate due to unknown causes did not vary significantly with respect to trap-nest length either among the nests collected from Site II $\left(\chi^{2}=0.75 ; \mathrm{df}=3 ; P>0.05\right)$ or among those established at Site III $\left(\chi^{2}=5.35 ; \mathrm{df}=3 ; P>0.05\right)$. However, at Site I, the nests occupying the 6.5$\mathrm{cm}$ trap-nests had a significantly higher mortality rate $\left(\chi^{2}=11.17 ; \mathrm{df}=3 ; P<0.05\right)$ than that observed for the other nests $\left(\chi^{2}=1.58 ; \mathrm{df}=2 ; P>\right.$ $0.05)$. At all three sites parasitism rates were relatively low, and no significant difference in
Figure 5. Mortality of Centris analis at different developmental stages according to trap-nest length from nests established from January 2006 to November 2007 at Site I and from January to November 200 at Sites II and III. (Bars topped by similar letters are not significantly different at $P<0.05$ ).

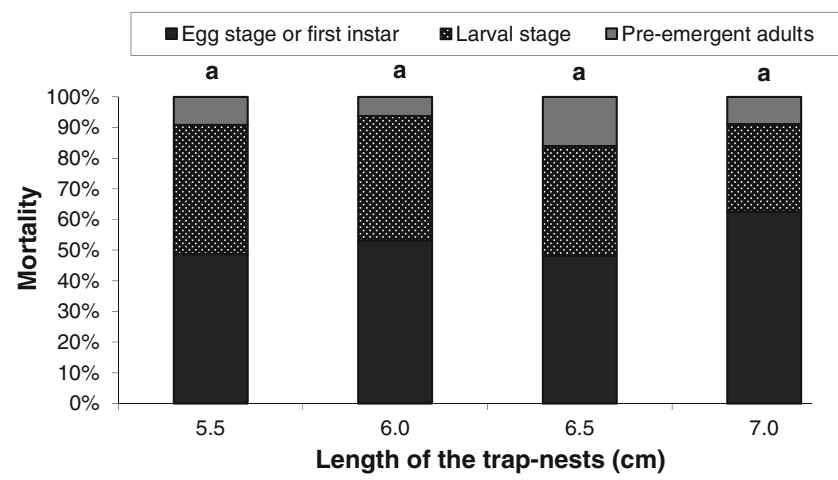


parasitism with respect to trap-nest length was observed among nests established at Site I $\left(\chi^{2}=\right.$ $1.39 ; \mathrm{df}=3 ; P>0.05)$ or between those occupying the two shortest trap-nests at Site II $\left(\chi^{2}=63.06\right.$; $\mathrm{df}=1 ; P<0,05)($ Table V).

\section{DISCUSSION AND CONCLUSIONS}

The occurrence of seasonality and fluctuations in annual frequencies of insects are population characteristics related to climatic factors and resource availability (Young 1982; Novotny and Basset 1998; Tommasi et al. 2004; Oertli et al. 2005) and have been reported by several authors who use trap-nests to study solitary bees and wasps (Camillo et al. 1995; Frankie et al. 1993, 1998; Morato et al. 1999; Pereira et al. 1999; Viana et al. 2001; Gazola and Garófalo 2003; Aguiar and Garófalo 2004; Aguiar et al. 2005; Thiele 2005). The pronounced seasonality showed by $C$. analis in the current study, similar to that reported by Gazola and Garófalo (2003), reflects the different climatic conditions between the seasons and the flowering periods of the plants utilized by bees.

Studies on the occupation of trap-nests by $C$. analis have shown that females can nest in cavities 0.48 to $1.0 \mathrm{~cm}$ in diameter, but in most cases, $0.6 \mathrm{~cm}$ is the preferred cavity diameter (Frankie et al. 1988; Frankie et al. 1993; Vieira de Jesus 1995; Aguiar et al. 2005; Thiele 2005; Oliveira and Schlindwein 2009; Vinson et al. 2010). The range of nesting cavity diameters used may be due to variability in female size, the low availability of preferential cavities, or perhaps to intra- or interspecific competition between bees and/or wasps nesting at the same site (Krombein 1967; Danks 1970; Fricke 1991; Strickler et al. 1996; Budrienè et al. 2004).

Studies reporting a preference by females for trap-nests with different lengths yet similar diameters revealed that, for Osmia cornuta (Latreille) (Megachilidae), the shortest trapnests were accepted less often than longer trap-nests, but the three longest lengths were similarly accepted (Bosch 1994b). In Ancistro-

Table V. Numbers and percentages of dead and emerged Centris analis individuals from nests established in trap-nests of different lengths from January 2006 to November 2007 at Site I, and from January to November 2007 at Sites II and III.

\begin{tabular}{|c|c|c|c|c|}
\hline \multirow[t]{2}{*}{ Site } & \multirow[t]{2}{*}{$\begin{array}{l}\text { Length of trap-nest } \\
\text { (in } \mathrm{cm} \text { ) }\end{array}$} & \multicolumn{2}{|c|}{$\begin{array}{l}\text { Number (and \%) of all cells } \\
\text { examined that died from }\end{array}$} & \multirow[t]{2}{*}{$\begin{array}{l}\text { Number (and \%) of } \\
\text { emerged bees }\end{array}$} \\
\hline & & Unknown causes & Parasitism & \\
\hline \multirow[t]{4}{*}{ I } & 5.5 & $41(40.6)^{b}$ & $7(6.9)^{\mathrm{a}}$ & $53(52.5)$ \\
\hline & 6.0 & $29(38.2)^{b}$ & $6(7.9)^{\mathrm{a}}$ & $41(53.9)$ \\
\hline & 6.5 & $23(59.0)^{\mathrm{a}}$ & $5(12.8)^{\mathrm{a}}$ & $11(28.2)$ \\
\hline & 7.0 & $17(27.9)^{b}$ & $6(9.8)^{\mathrm{a}}$ & $38(62.3)$ \\
\hline \multirow[t]{4}{*}{ II } & 5.5 & $15(26.8)^{\mathrm{a}}$ & $3(5.4)^{\mathrm{a}}$ & $38(67.8)$ \\
\hline & 6.0 & $19(27.5)^{\mathrm{a}}$ & $4(5.8)^{\mathrm{a}}$ & $46(66.7)$ \\
\hline & 6.5 & $17(29.3)^{\mathrm{a}}$ & $0(0.0)$ & $41(70.7)$ \\
\hline & 7.0 & $21(27.3)^{\mathrm{a}}$ & $0(0.0)$ & $56(72.7)$ \\
\hline \multirow[t]{4}{*}{ III } & 5.5 & $20(46.5)^{\mathrm{a}}$ & $3(6.9)$ & $20(46.5)$ \\
\hline & 6.0 & $16(35.6)^{\mathrm{a}}$ & $0(0.0)$ & $29(64.4)$ \\
\hline & 6.5 & $16(35.6)^{\mathrm{a}}$ & $0(0.0)$ & $29(64.4)$ \\
\hline & 7.0 & $18(32.1)^{\mathrm{a}}$ & $0(0.0)$ & $38(67.9)$ \\
\hline
\end{tabular}

Values followed by different letters, in the same column and for the same site, are significantly different at $P>0.05$ 
cerus gazella (Panzer) (Eumeninae), trap-nest length did not affect the proportion of nests occupied by wasps (Wearing and Harris 1999). The results obtained in this study showed that in only one area did the females utilize the trapnests differently, with $5.5-\mathrm{cm}$ trap-nests being the most attractive in that area. If the similar preference for trap-nests of different lengths can be explained by the small difference in length between the shortest and longest trap-nests, the preference for the shortest trap-nests in Site I was an unexpected result because, theoretically, the females should prefer longer trap-nests, which would provide the greatest productivity as a result of rearing more offspring per nest. This would lessen the amount of energy required by $C$. analis females to find another cavity and construct more cells. This idea is corroborated by the tendency observed in the present study for the number of brood cells to increase with increasing trap-nest length, as also reported by Tepedino and Parker (1984) for Hoplitis fulgida (Cresson), Bosch (1994a, b) for $O$. cornuta, Wearing and Harris (1999) for $A$. gazella, Aguiar and Garófalo (2004) for Centris tarsata Smith, and Aguiar et al. (2005) for $C$. analis. Thus, the lower fecundity observed for females that nested at Site I can be explained by the high frequency with which the shortest trapnests were occupied, which usually supported only three brood cells.

Regardless of the length of the trap-nest occupied by $C$. analis females, female cells were longer than male cells. Moreover, the arrangement of the sexes, with males being produced in the outer cells and females in the inner cells followed the usual pattern for other species nesting in trap-nests (Krombein 1969) and that reported by Vieira de Jesus and Garófalo (2000) for this species. Trap-nest length, however, had a meaningful influence on the resulting sex ratio among offspring, as also reported by Stephen and Osgood (1965) for Megachile rotundata (Fabricius), Torchio and Tepedino (1980) for Osmia lignaria propinqua Cresson, Tepedino and Parker (1984) for $H$. fulgida, Bosch (1994a, b) for O. cornuta and Gruber et al. (2011) for O. bicornis (Linnaeus
1758). Thus, as observed in this study and in all examples above, the male-biased sex ratio decreases as the length of the trap-nest increases. In $C$. analis the shift in the sex ratio resulted from the increased production of females as the number of brood cells increased in response to increasing trap-nest length. Interestingly, the observed decrease in the percentage of females produced per nest from the innermost cells was due to increased production of them from the outermost cells. The emergence of greater numbers of females as trap-nest length increased was also reported by Wearing and Harris (1999) for A. gazelle and Gruber et al. (2011) for $O$. bicornis. In the first case, the sex ratio did not change in response to trap-nest length while in the latter, the percentage of females increased significantly with increasing length of the bamboo canes.

In general, survival from the egg to the adult stage in $C$. analis was higher than that reported in previous studies carried out at Site I (Vieira de Jesus and Garófalo 2000; Gazola and Garófalo 2003; Couto and Camillo 2007). As also observed in those studies, the main causes of immature mortality were unknown. Because the mortality rates from those causes did not differ among the nests, it can be concluded that the causes of this mortality were independent of trap-nest dimensions.

Mortality rates were different among sites, however, with the loss of immatures by parasitism and unknown causes being highest at Site I. Although spatial variation in parasitism rates, as observed in this study, can be due to the diversity of natural enemies attacking the host, the intensity of attacks (Tepedino and Parker 1983 and references therein; Tepedino and Parker 1984) and/or the abundance of attacks as an explanation for the variation in mortality rates from unknown causes in our study requires more detailed information on the agents responsible.

Parasitism and other mortality rates observed at each study site showed no association with trap-nest dimensions, with the exception of the nests established in $6.5-\mathrm{cm}$ trap-nests at Site I, 
which had a mortality rate from unknown causes higher than that of the other trap-nests there. At both Site I, where attacks by natural enemies were observed with higher frequency, and at Site II, there were no differences among nests of different dimensions in the probability of a nest being attacked by enemies. It can therefore be concluded that, in general, trap-nest length has no detectable influence on the immature mortality of $C$. analis from unknown causes or attacks by enemies. These results do not allow saying that the length of trap-nests influenced the immature mortality of $C$. analis, unlike those by Oliveira and Schlindwein (2009) who reported that nests established in larger cavities were more vulnerable to mortality factors.

The present study shows that an increase in the production of $C$. analis females can be achieved by simply increasing the length of trap-nests. Although the longest trap-nest was $7.0 \mathrm{~cm}$ in this study, future studies utilizing longer trap-nests should determine the most suitable trap-nest length for rearing optimal numbers of females.

\section{ACKNOWLEDGMENTS}

We are grateful to J.C. Serrano and S. Mateus for technical help. We also thank two anonymous reviewers for comments that improved the manuscript. J.D.S. Alonso received a grant from Conselho Nacional de Desenvolvimento Científico e Tecnológico $(\mathrm{CNPq})$. This study was supported by a grant of Conselho Nacional de Desenvolvimento Científico e Tecnológico to C. A. Garófalo.

Effets de la longueur de la cavité sur la taille du nid, la sex-ratio et la mortalité de Centris (Heterocentris) analis (Hymenoptera, Apidae, Centridini)

Centris analis / piège à nidification / sex ratio / mortalité pré-imaginale / ennemi naturel

Die Rolle der Nisthölenlänge für die Nestgrösse, Geschlechterverhältnis und Mortalität von Centris (Heterocentris) analis (Hymenoptera, Apidae, Centridini)

Centris analis / Nistfalle / Geschlechterverhältnis / präimaginale Mortalität / natürliche Feinde

\section{REFERENCES}

Aguiar, C.M.L., Garófalo, C.A. (2004) Nesting biology of Centris (Hemisiella) tarsata Smith (Hymenoptera, Apidae, Centridini). Rev. Bras. Zool. 21, 477486

Aguiar, A.J.C., Martins, C.F. (2002) Abelhas e vespas solitárias em ninhos-armadilha na Reserva Biológica Guaribas (Mamanguape, Paraíba, Brasil). Rev. Bras. Zool. 19, 101-116

Aguiar, C.M.L., Garófalo, C.A., Almeida, G.F. (2005) Trap-nesting bees (Hymenoptera, Apoidea) in areas of dry semideciduous forest and caatinga, Bahia. Brazil. Rev. Bras. Zool. 22, 1030-1038

Bosch, J. (1994a) The nesting behaviour of the mason bee Osmia cornuta (Latr) with special reference to its pollinating potential (Hymenoptera, Megachilidae). Apidologie 25, 84-93

Bosch, J. (1994b) Improvement of field management of Osmia cornuta (Latreille) (Hymenoptera, Megachilidae) to pollinate almond. Apidologie 25, 71-83

Bosch, J., Kemp, W.P. (2001) How to manage the blue orchard bee as on orchard pollinator. Sustainable Agriculture Network, Beltsville

Bosch, J., Kemp, W.P. (2002) Developing and establishing bee species as crop pollinators: the example of Osmia spp. (Hymenoptera: Megachilidae) and fruit trees. Bull. Entomol. Res. 92, 3-16

Budrienė, A., Budrys, E., Nevronyte, Ž. (2004) Solitary Hymenoptera Aculeata inhabiting trap-nests in Lithuania: Nesting cavity choice and niche overlap. Latvijas Entomologs 41, 19-31

Buschini, M.L.T. (2006) Species diversity and community structure in trap-nesting bees in Southern Brazil. Apidologie 37, 58-66

Camillo, E., Garófalo, C.A., Serrano, J.C., Muccillo, G. (1995) Diversidade e abundância sazonal de abelhas e vespas solitárias em ninhos armadilhas (Hymenoptera, Apocrita, Aculeata). Rev. Bras. Entomol. 39, 459-470

Castro, M.S. (2002) Bee fauna of some tropical and exotic fruits: Potential Pollinators and their Conservation. In: Kevan, P.G., Imperatriz-Fonseca, V.L. (eds.) Pollinating Bees: The Conservation link between Agriculture and Nature, pp. 275-288. Ministry of the Environment, Brasília

CIIAGRO (2011) Centro Integrado de Informações Agrometereológicas. Resenha Agrometeorológica por local. http://www.ciiagro.sp.gov.br/ciiagroonline/ Listagens/Resenha/LResenhaLocal.asp

Couto, R.M., Camillo, E. (2007) Influência da temperatura na mortalidade de imaturos de Centris (Heterocentris) analis (Hymenoptera, Apidae, Centridini). Iheringia 97, 51-55

Danks, H.V. (1970) Biology of some stem-nesting aculeate Hymenoptera. Trans. R. Entomol. Soc. Lond. 122, 323-399 
Frankie, G.W., Vinson, S.B., Newstrom, L.E., Barthell, J.F. (1988) Nest site and habitat preferences of Centris bees in Costa Rican dry forest. Biotropica 20, 301-310

Frankie, G.W., Newstrom, L.E., Vinson, S.B., Barthell, J.F. (1993) Nesting-habitat preferences of selected Centris bee species in Costa Rican dry forest. Biotropica 25, 322-333

Frankie, G.W., Thorp, R.W., Newstrom-Loyd, M., Rizzard, M.A., Barthell, J.F., Griswold, T.L., JongYoon, K., Kappagoda, S. (1998) Monitoring solitary bees in modified wildland habitats: implications for bee ecology and conservation. Environ. Entomol. 27, 1137-1148

Freitas, B.M. (1997) Number and distribution of cashew (Anacardium occidentale) pollen grains on the bodies of its pollinators, Apis mellifera and Centris tarsata. J. Apic. Res. 36, 15-22

Freitas, B.M., Paxton, R.J. (1998) A comparison of two pollinators: the introduced honey bee Apis mellifera and an indigenous bee Centris tarsata on cashew Anacardium occidentale in its native range of $\mathrm{NE}$ Brazil. J. Appl. Ecol. 35, 109-121

Freitas, B.M., Alves, J.E., Brandão, G.F., Araujo, Z.B. (1999) Pollination requirements of West Indian cherry (Malpighia emarginata) and its putative pollinators Centris bees, in NE Brazil. J. Agric. Sci. 133, 303-311

Fricke, J.M. (1991) Trap-nest bore diameter preferences among sympatric Passaloecus spp. (Hymenoptera: Sphecidae ). Great Lakes Entomol. 24, 123-125

Garófalo, C.A. (2000) Comunidades de abelhas (Hymenoptera, Apoidea) que utilizam ninhos-armadilha em fragmentos de matas do Estado de São Paulo. Anais do IV Encontro sobre Abelhas, Ribeirão Preto, Brazil 4, 121-128

Garófalo, C.A., Martins, C.F., Alves-dos-Santos, I. (2004) The brazilian solitary bee species caught in trap nests. In: Freitas, B.M., Pereira, J.O.P. (eds.) Solitary bees: Conservation, Rearing and Management for Pollination, pp. 77-84. Imprensa Universitária, Fortaleza

Gazola, A.L., Garófalo, C.A. (2003) Parasitic behavior of Leucospis cayennensis Westwood (Hymenoptera: Leucospidae) and rates of parasitism in populations of Centris (Heterocentris) analis (Fabricius) (Hymenoptera: Apidea: Centridini). J. Kans. Entomol. Soc. 76, 131-142

Gazola, A.L., Garófalo, C.A. (2009) Trap-nesting bees (Hymenoptera: Apoidea) in forest fragments of the State of São Paulo, Brazil. Genet. Mol. Res. 8, 607-622

Gruber, B., Eckel, K., Everaars, J., Dormann, C.F. (2011) On managing the red mason bee (Osmia bicornis) in apple orchards. Apidologie 42, 564-576

Krombein, K.V. (1967) Trap-nesting wasps and bees: life histories, nests and associates. Smithsonian Press, Washington
Krombein, K.V. (1969) Life history notes on some Egyptian solitary wasps and bees and their associates (Hymenoptera: Aculeata). Smithsonian Contr. Zool. 19, 1-18

Maccagnani, B., Burgio, G., Stanisavljević, L.Ž., Maini, S. (2007) Osmia cornuta management in pear orchards. Bull. Insectol. 60, 77-82

Maeta, Y. (1978) Comparative studies on the biology of the bees of the genus Osmia in Japan, with special reference to their management for pollination of crops (Hymenoptera, Megachilidae). Bull. Tohoku Natl. Agric. Exp. Stn. 57, 1-121

Morato, E.F., Campos, L.A.O. (2000) Efeitos da fragmentação florestal sobre vespas e abelhas solitárias em uma área da Amazônia Central. Rev. Bras. Zool. 17, 429-444

Morato, E.F., Garcia, M.V.B., Campos, L.A.O. (1999) Biologia de Centris Fabricius (Hymenoptera, Anthophoridae, Centridini) em matas contínuas e fragmentos na Amazônia Central. Rev. Bras. Zool. 16, 1213-1222

Moure, J.S. (1960) Notes on the types of the Neotropical bees described by Fabricius (Hymenoptea: Apoidea). Studia Entomol. 3, 97-160

Novotny, V., Basset, Y. (1998) Seasonality of sap sucking insects (Auchenorrhyncha, Hemiptera) feeding on Ficus (Moraceae) in a lowland rain forest in New Guinea. Oecologia 115, 514-522

Oertli, B., Biggs, J., Céréghino, R., Grillas, P., Joly, P., Lachavanne, J.B. (2005) Conservation and monitoring of pond biodiversity: introduction. Aquat. Conserv: Mar. Freshw. Ecosyst. 15, 535-540

Oliveira, R., Schlindwein, C. (2009) Searching for a manageable pollinator for acerola orchards: The solitary oil-collecting bee Centris analis (Hymenoptera: Apidae: Centridini). J. Econ. Entomol. 102, 265-273

Pais, M.P., Varanda, E.M. (2010) Arthropod recolonization in the restoration of a semideciduous forest in southeastern Brazil. Neotrop. Entomol. 39, 198-206

Pereira, M., Garófalo, C.A., Camillo, E., Serrano, J.C. (1999) Nesting biology of Centris (Hemisiella) vittata Lepeletier in southeastern Brazil (Hymenoptera, Apidae, Centridini). Apidologie 30, 327-338

Pitts-Singer, T.L., James, R.R. (2005) Emergence Success and Sex Ratio of Commercial Alfalfa Leafcutting Bees from the United States and Canada. J. Econ. Entomol. 98, 1785-1790

Stephen, W.P., Osgood, C.E. (1965) Influence of tunnel size and nesting medium on sex ratio in a leaf-cutter bee, Megachile rotundata. J. Econ. Entomol. 58, 965-968

Strickler, K., Scott, V.L., Fischer, R.L. (1996) Comparative nesting ecology of two sympatric leafcutting bees that differ in body size (Hymenoptera: Megachilidae). J. Kans. Entomol. Soc. 69, 26-44

Systat Software Inc (2008) SigmaPlot for Windows, Version 11.0 [http://www.systat.com] 
Tepedino, V.J., Parker, F.D. (1983) Nest size, mortality and sex ratio in Osmia marginata Michener. Southwest. Entomol. 8, 154-167

Tepedino, V.J., Parker, F.D. (1984) Nest selection, mortality and sex ratio in Hoplitis fulgida (Cresson) (Hymenoptera: Megachilidae). J. Kans. Entomol. Soc. 57, 181-189

Tepedino, V.J., Torchio, P.F. (1989) Influence of nest hole selection on sex ratio and progeny size in Osmia lignaria propinqua (Hymenoptera: Megachilidae). Ann. Entomol. Soc. Am. 82, 355-360

Thiele, R. (2005) Phenology and nest site preferences of wood-nesting bees in a Neotropical lowland rain forest. Stud. Neotrop. Fauna Environ. 40, 39-48

Tommasi, D., Higo, H.A., Winston, M.L. (2004) Bee diversity and abundance in an urban setting. Can. Entomol. 136, 851-869

Torchio, P.F., Tepedino, V.J. (1980) Sex ratio, body size and seasonality in a solitary bee, Osmia lignaria propinqua Cresson (Hymenoptera: Megachilidae). Evolution 34, 993-1003

Viana, B.F., Silva, F.O., Kleinert, A.M.P. (2001) Diversidade e sazonalidade de abelhas solitárias (Hymenoptera: Apoidea) em dunas lirorâneas no nordeste do Brasil. Neotrop. Entomol. 30, 245-251

Vicens, N., Bosch, J., Blas, M. (1994) Biology and population structure of Osmia tricornis Latreille
(Hymenoptera: Megachilidae). J. Appl. Entomol. 117, 300-306

Vieira de Jesus, B.M. (1995) Comportamento de nidificação e abundância sazonal de Centris (Heterocentris) analis (Fabricius, 1804) (Hymenoptera, Anthophoridae), MSc thesis, FFCLRP-USP, Ribeirão Preto, Brazil

Vieira de Jesus, B.M., Garófalo, C.A. (2000) Nesting behaviour of Centris (Heterocentris) analis (Fabricius) in southeastern Brazil (Hymenoptera, Apidae, Centridini). Apidologie 31, 503-515

Vinson, S.B., Frankie, G., Cônsoli, R. (2010) Description, comparison and identification of nests of cavity-nesting Centris bees (Hymenoptera: Apidae: Centridini) in Guanacaste Province, Costa Rica. J. Kans. Entomol. Soc. 83, 25-46

Wearing, C.H., Harris, A.C. (1999) Evaluation of the predatory wasp, Ancistrocerus gazella, for biological control of leafrollers in otago fruit crops: Prey composition, nest structure and wasp productivity from artificial nests. Biocontrol Sci. Technol. 9, 315-325

Young, A.M. (1982) Population biology of tropical insects. Plenum Press, New York

Zar, J.H. (1984) Biostatistical analysis, 2nd edn. Prentice-Hall, Englewood Cliffs 